\title{
Land Policy Instruments in Nepal
}

\author{
Ram Bhandari Chhetri \\ Department of Civil Engineering, Central Campus, Pulchowk, IOE, TU, Lalitpur, Nepal \\ Corresponding Email: errbc@wlink.com.np
}

\begin{abstract}
Corporate mobilization can be made realistic if policy facilitation is provided by the government sector. This research study aimed at exploring the possibility of a mechanism that will attract substantial investments from the private sector by mobilizing the existing capital market. To do so, the research within its objective framework examined the essential policy framework from the literature review, the existing legal, financial and planning and housing policies posing impediments to the prospective participation of the corporate sector in land and housing activities. This included but not necessarily restricted to the land administration, land legislatives, cadastral mapping system and current planning techniques used and the operational constraints it would pose upon the prospective mobilization of the corporate financing in land and housing development. The research study then finally intended to arrive at the framework that could possibly facilitate or promote corporate finance in land and housing sector in a greater way. The finding from the research is then translated into a framework for increased participation for corporate sector in land and housing that chiefly included following aspects.
\end{abstract}

\section{Land Policy Instruments}

\section{Land Policy Framework}

Urban land policy according to [13] is the policy documents which should include provisions for increasing supply of serviced land especially for urban poor through land use regulations, policy for involving private sector, maximization of the availability of housing per unit of land, efficient and innovative way of land administration and information system.

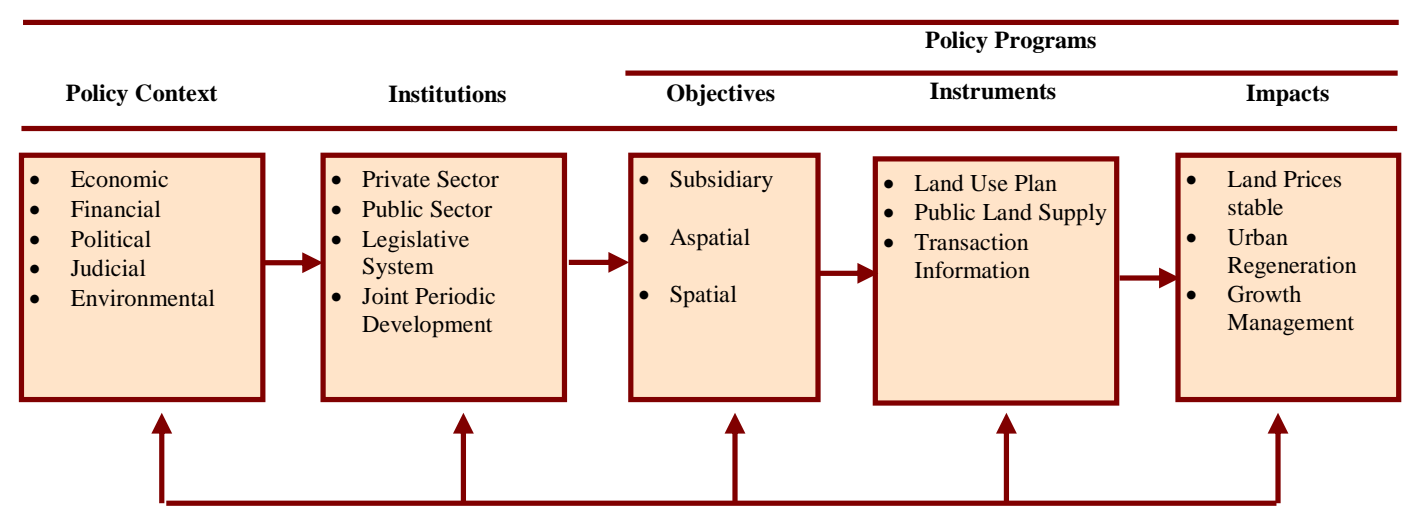

Source: Urban Land Markets, OECD, 1992

Figure 1: Urban Land Policy Framework (cf. [18]) 
A comprehensive framework for such urban policy should address the complexities of land related issues and its recursive nature, it interrelations with other economic sectors, agencies and policy programs (Figure 1). The policy prescriptions in these documents are materialized through number of policy instruments.

\section{Land Registration Systems}

Traditionally, land transfers became a legally binding agreement upon the delivery of the transfer price or an oral agreement. However, it became increasingly necessary to develop systems, which would clarify ownerships and minimize disputes, provide title security and provide transparency in government's revenue collection. However, in most of the developing countries, the registration process is often very time-consuming.

Box 1: Land Registration System in Developing Countries (Source: [18])

Deeds Registration System: In this system, the transfer document (the deed) itself is registered. The deed does not prove the ownership and the chain of ownership has to be traced back either by lawyers or the land registration authority.

Title Registration System: In this system the certificate itself is the proof of ownership. This system was developed in the United Kingdom and exists in many Anglo-Saxon countries and countries with such influence. In many countries with this system, the land registration system is not complete either because it is not compulsory to register transfers or because it is only necessary register when land is sold or subject to long lease (e.g. England and Wales). The Torrens system is a variant of the title registration system developed in Australia. The advantage is that there are two certificates to each parcel and the original is kept at the land registry. An ownership transfer is merely endorsed on the back of both the original and duplicate. Variations of this system have been adopted in countries such as Thailand, Malaysia and Kenya.

The private convenience system: It is the most common system in developing countries. It is based on the system to register deeds. However, only about 10 to 20 percent of transactions are registered for example in Bangladesh and Pakistan with the remaining transactions conveyed either formally or informally with or without a person of legal training involved (Farvacque and McAuslan, 1992). A practice has gradually developed in most societies whereby the land transaction should be written and that there should be a witness.

According to Doebele ([9] cf. [18]), "in those countries in which the rate of urbanization in the next two decades is expected to be most rapid, the cadastral systems tend to be weakest." As a result it becomes very difficult to administer the urban land in an equitable manner. He is of the view that establishment of efficient cadastral system is therefore now regarded as much a part of basic infrastructure as roads and electric grids, and an essential element to expedite virtually all other forms of development. He estimates that 50 percent of all World Bank urban projects between 1972 and 1982 have encountered additional costs and/or substantial delays due to inadequate cadastral and property tax systems. The effective Land Registration system, according to ESCAP (1998), includes the written record or register with information on each 
parcel which is completed with a detailed description of the parcel in the form of map/ survey measurements.

The written information and maps when combined should provide, according to [18] the following benefits:

- Security of ownership and tenure rights: This is the most important impact. It reduces the amount of land disputes, which currently is a major issue in developing countries. The security of ownership also stimulates land development.

- More efficient land transfers: The cost of delays for permits is a serious constraint in most of the developing countries, and an efficient registration system makes transfers easier, less expensive and more secure.

- Security of credit: The land title can be used as collateral for loans. This security has a positive impact on the productivity of the land since it enables the release of major financial resources for investment in the land.

- Public control of land markets and intervention: Policies such as land redistribution and control over foreign land ownership are difficult to implement without a functioning land registration system.

- Support for the land taxation system: The expenses for improving the cadastral system would, in actual fact, be quickly covered by increased property tax revenues.

- Improved land use and management: It can directly provide better information on land ownership and rights for physical planning as well as facilitate the development of other planning tools such as information banks covering land use and values, population etc. It can also provide a tool to restrict certain land uses with a negative environmental impact.

'Most of the developing countries still resort to traditional land registration method against the advantage of registration system based on parcels that could lead to a more advanced land information system. Many developing countries are reluctant to adopt modern and efficient registration system due to limited institutional, technical, economical resources despite the fact that the cost involved in upgrading the land registration can be recovered within a very short time span with revenues from land transfers and property taxes as in case of Thailand ([11] cf. [18]). To overcome these limitations, 'progressive model' has been recommended for developing countries, which essentially means that when a new cadastral/ land registration system is introduced, or an old improved, its design should be such that, although technically simple, it can be upgraded easily and readily adaptable. Larsson ([15], cf. [18]) suggests different types of simplifications, which are available in a progressive system:

- Reduction of functions

- Establish the cadastre on a higher scale initially, for example, the block or ward unit. This would not include registration of each parcel or owner.

- Use simpler methods of delimitation and demarcation- there exists even an example of a successful system where dwellings are identified on aerial photos.

- Reduce standards of accuracy for land registration surveys

- Minimize fieldwork- use existing maps and records as much as possible

- Establish provisional registers 
- Selectivity- selection of land units can be based either on registration of individual landowners or an area. The system may or may not include compulsory registration.

The efficient land registration system is also instrumental in shaping the land information system. In increasingly complex society with an abundance of data information, there are many reasons for developing a system to attain and combine information on land in a systematic, rational and efficient manner. The modern land information system, in the view of assisting urban land market to become more efficient, can do so by helping monitor land market by providing the transaction information, facilitating conveyance process and subsequently ensure the transparency of the transactions and making records available for land market operations.

\section{Land Tenure and Property Rights}

Land tenure is an important instrument for the management of urban land and appropriate tenure system has the ability to respond to the pressures of rapid urban growth (Haque, 1997). However, [9] (in ESCAP cf. [18]) notes that land tenure systems of many developing countries do not facilitate efficient land use but reinforce prevailing inequalities of wealth and access to opportunities. He has defined four policy objectives by which land tenure systems may be judged:

- Efficiency: Does the system encourage a smoothly operating land market?

- Equity: Does the system provide reasonable access for all income groups to land for housing and other needs?

- Compatibility: Does the tenure system integrate well with other laws and policies regarding land such as planning, taxation and provision of public services?

- Continuity: Does the system integrate well with the cultural, social and political heritage of the country?

The property right and tenure system emerges out stronger if viewed within the framework of aforementioned policy objectives, major issues like how to modernize and reform tenure system on the basis of freehold, extent and nature of regulatory controls required over the landlord/ tenant relationship and modalities on general control over transactions.

In practice, many developers, due to the obvious advantages (especially in terms of time) freehold has, prefer the freehold ownership of land property to leasehold. However the establishment of property right and tenure system has appeared as a major impediment in developing countries resulting in the need for policy reform. Similarly, World Bank (1992) states that the systems of regulating the landlord-tenant relationship should be geared to the type of landlord-tenant relationship that exists. On one hand, small tenancies may need no more than a local reference point for ironing out small disputes. Large-scale commercial landlordism, on the other hand, may need more formal centralized regulation. The third issue- restriction on transaction of land also needs to be viewed in terms of securing the interest of poor and the sustainable urban development.

\section{Land Use Regulations}

The primary objective concerning land use in urban areas is that the land should be used optimally, and should be equitably distributed amongst the various sections of population for fulfilling their requirements for shelter and other uses. However this task is increasingly 
becoming difficult in urban areas of developing countries in the light of massive population growth and increasing urbanization rate.

As a result, government uses a wide variety of tools to intervene in land market with a view to perfecting the market imperfections and failures, to remove the social costs for land market and to redistribute the resources to the disadvantaged group in the society. Important tools that a government must put into use to regular urban land market so that private sector could be motivated to participate according to Uprety (2001) are:

- Planning Tools: The most common of these tools are comprehensive general plans, master plans, strategic plans and structure plans. The broad objective of these plans is to guide the development of the city for a specified time period and to promote the landuse pattern, which most efficiently fulfils the objectives of the government.

- Zoning Ordinances: Courtney (in ESCAP) defines zoning as "the demarcation of a city by ordinances and the establishment of regulations to govern the use of the zoned land. It also includes general rules about location, bulk, height, and thus plot ratios, shape, use, and coverage of structures within each zone". Zoning regulates the use of land in areas for residential, commercial, industrial, agricultural or other land use.

- Building Regulations/Bye Laws: Building regulations are formulated in order to achieve the objective of securing socially accepted minimum standards. The building codes are developed or modified in such a way to comply with the economic, sociocultural, and political background of the country.

- Subdivision Regulation: The development of rural urban land is regulated by land subdivision regulations as guided by overall zoning. The regulations define standards for layout and lot sizes, street improvements and procedures for assigning private land for public purposes. Subdivisions provide the essential characteristics of land uses, street patterns and public utilities.

'However, regulations in many countries are often been the subject of criticism because of their rigidity and high costs that they impose on the developer and ultimately to the purchaser. The most commonly pertinent issues in this regard are regulations based on outdated and inappropriate planning, long period required to implement master plans resulting in achieving coordinated financial and spatial planning, centralization due to obsolete planning ordinances and, approval process and procedural delays (Uprety 2001)'.

\section{Land Policy Reform: Needs and Guidelines}

The need for the reformation arises from the existing land policy's limitations to cope with the growing urbanization its impact on city's productivity, to make land use planning market friendly and complexities in regulatory mechanisms in a changing political and economic context. Dowall ([10] cf. [18]) explains that government's comprehensive approaches based on traditional paradigm of rational planning and implementation as a land policy instrument has seldom succeeded as they do not consider city's actual economic potential and they largely ignore the capacity of households and business to pay for land and properties.

From the perspective of private sector's involvement, he further argues that the policy reform is required to provide the framework for government in assisting private developers, to undertake risky projects avoided by developers, to made land information system more efficient and to 
minimize "too centralized" government management of urban land. According to him, the following guidelines should provide the basic guidelines for the land reform framework-

- The land market assessment

- Decentralizations of land management authorities at local levels

- Deregulation of urban land policy and regulation to reduce land prices and increase land market efficiency

- Curtailment of public land development authorities

- Improvement of land market operations to avoid illegal land transactions

- Provision for financial \& spatial structure to install infrastructure networks

\section{Tools of Urban Land Development}

\section{General}

Public sector has the ability and responsibility to use available tools to guide the urban land development for the equitable benefits of the masses. These tools are related to acquisition of land, their development and then distribution to the public. In this context, nationalization, expropriation, and land banking are used as tools to make land available for the development. Land Readjustment, Guided Land Development, Site and Services, and Land Sharing are other means used for actual development of available land. From the perspective of private sector's involvement in land development, government's role in using these tools are of paramount importance as they facilitate much required land and development options for the private sector.

\section{Land Acquisition}

The main tools used for land acquisitions, apart from land readjustment techniques, are nationalization of urban land and land banking. In nationalization, public sector gets hold of land eliminating the existing market for larger public goods using power of eminent domain which is compulsory land acquisition by public sectors through the existing laws and policies backing it. Similarly, the concept of land banking implies that the government acquires land areas in advance of needs. It is effective way of controlling the land market in terms of preventing land speculation and illegal land transactions. It is effective in urban fringe areas where purchase of land is relatively cheap. The fringe areas are areas where urbanization is generally expected to take place.

World Bank suggests that the land banking has to be developed on a national scale as an integral part of land-use policies and has to be used as one of a number of instruments to advance those policies. It cannot be used as a substitute for national land policies, nor can it be used in isolation of other instruments. This is because such land banking needs large amount of land which often becomes difficult to obtain due to the number of landowners and the increase of land value because of the information leakage within the government offices or even the speculation by government officials themselves. Some countries have even mandatory regulations to announce the public authority about its intention to buy land in advance resulting price escalation in the area of demand. 


\section{Land Acquisition Act and Related Regulations in Nepal}

The Town Development Committee Act 1963 permits the Town Development Committee to acquire land and to prohibit construction of buildings on any land, category of lands, or zone of the town upon payment of reasonable compensation for preservation of agricultural land, forests, watersheds, or for settlement development. The landowners must be fully compensated within one year. This requirement, if implemented, could have major cost implications for any attempt to preserve or protect land in the Valley Area.

Town Planning Project Implementation Act 1973 is more limited in scope than the 1963 Act, since it applies only to regional development centers and was designated to deal with discrete project areas rather than whole towns, cities or regions. Nevertheless, it is an important law that has served as a basis for some of the institutional structures for urban planning in the Valley. Since the Act allows TPIC the power to acquire and prohibit property transaction, building structure or tamper with natural and cultural resources without the approval of the Board, clear planning boundaries must be defined.

The Land Acquisition Act 1977 empowers the government to purchase land for public purposes and specifies that tenants on expropriated land are entitled to receive $25 \%$ of the total compensation paid. Tenants must also receive full value of any house they may have constructed. The Act contains a "quick take" provision empowering NG to "occupy a parcel in special circumstances" simply by issuing a notice. Key features of this Act are as follow:

a) Time limit within which the compensation must be paid is mentioned.

b) Guideline for the amount of compensation to be paid is not adequate.

c) It is mentioned that if the acquired land is not required for the original purpose due to various reasons, NG can use it for another similar purpose.

\section{Process of Land Acquisition}

Any NG agency is authorized to acquire land and an offer of any NG institution may initiate a land acquisition proceeding. If the land is found suitable, a notice of intent to acquire is issued. At this point, the local Land Administrator or Revenue Officer suspends processing of any further transactions concerning the land.

In practice, requests for land initiate among NG agencies but acquisition itself is carried out under the guidance of the Chief District Officer (CDO) and Compensation Committee which engages in negotiations with land owners.

In practice usually following steps are adopted while acquiring the land:

i) Preparation of project documents

a) Type of land required

b) Location

c) Quantity

d) The reason for the required land

e) By what time land should be available

ii) Information collection 

a) Number of land holdings
b) Number of land owners
c) Number of tenants

iii) Public notice regarding locus standing (hak dabi) from the related office. Duration of this period is of three months.

a) Preparation of document (list) of different types of land and land owners

b) Handing of the list of $\mathrm{CDO}$ office through related Ministry

c) Public notice regarding land acquisition, compensation from $\mathrm{CDO}$ office

d) Clearing up or estimation list account from Survey Department and Land Revenue office.

Here follows the problems affecting land acquisition:

a) rapidly rising land prices which bag down negotiations and payment of compensations;

b) many land owners still do not have certificate of land title

c) inadequate registered records (e.g. grandson uses the asset but the dead grandfather still holds the land title, transfer of land ownership has not been done yet)

d) inadequate or not updated maps

e) land owned by different trusts

f) land owned by many people

g) people do not come to claim their land or do not come to take compensation

h) small landholdings

i) people do not want to pay for betterment value

\section{Land Development}

As stated earlier one of the most powerful tools that a government has to intervene in land markets is land development. A government has two options for its intervention: it can either develop land itself or it can promote land development through the private sector. The land development system prevalent in mixed economy Asian countries, according to Archer ([1] cf. [18]) includes three basic types. They are the private land ownership and development system (government provides the major site infrastructure, private land subdivision and building development on the site follows), the government land ownership system and development system (government provides all onsite and offsite infrastructures followed by both private and government building development) and the private land ownership and government land development system (government provides only the off-site infrastructure on private land assembled through land pooling/ readjustment method followed by subdivision of land lots on private ownership and private building). The tools to efficient urban land management through land development in developing countries could be understood through four widely used development techniques.

\section{Land Pooling/ Readjustment}

This is a widely used technique for promoting efficient, sustainable and equitable land development in the urban fringes. The concept of land readjustment has been used in various 
countries of the world for at least two hundred years. It has been most successfully used in Japan and Republic of Korea in recent years. The concept of land readjustment is to assemble small rural land parcels into a large land parcel, provide it with infrastructure in a planned manner and return the reconstituted land to the owners, after deducting the cost of the provision of infrastructure and public spaces by the sale of some serviced land.

A land readjustment scheme is typically initiated by the municipal or the national government designating an area which is about to be converted from agricultural to urban land use. A subdivision plan is developed for a unified planning of the area. Provision of infrastructure and services is financed by the sale of some of the plots within the area, often for commercial activities. The original landowners are provided plots within the reshaped area, which, although smaller in size, now have access to infrastructure and services. Land readjustment projects work best when they are implemented in small to medium-sized areas. Phasing could be used within larger areas.

\section{Guided Land Development}

Guided land development (GLD) uses the provision of infrastructure as a mechanism to guide urban development. It is a land management technique for guiding the conversion of privately owned land in the urban periphery from rural to urban uses. The principle behind guided land subdivision is that the government agency entrusted with urban planning or land development proactively selects the direction where it feels urban development should take place and provides infrastructure in those areas.

'Governments can use infrastructure investment policies to guide the direction of land development, as well as, to ensure that land development is efficient, environmentally sound and equitable. This encourages private land developers to develop land in that area. It is done in partnership with landowners who pay for the cost of servicing their land through donation of land for public infrastructure and payment of betterment levy. It uses a combination of traditional government role of providing infrastructure and the enforcement of land subdivision regulations. The key advantage of the approach is that it is less costly than outright land acquisition and more equitable than land banking [18].

\section{Site and Services}

Site-and-services schemes provide the target group with a plot and basic infrastructure, such as water, roads and sanitation facilities. The beneficiaries either lease or buy the allocated land. Often, they are provided access to a loan with reasonable terms as well as an additional loan for the construction of a house. Although typically not included in the project, it is expected that the plot owner would eventually build a house of reasonable standard. During the 1970s and 1980s, sites-and-services schemes were implemented in nearly 100 countries mostly on the behest of international agencies like the United Nations and the World Bank.

\section{Land-sharing}

Land sharing has been implemented with success in Thailand and to a lesser degree in the Philippines. The concept behind land sharing is that the landowner and the land occupants (squatters or tenants) reach an agreement whereby the landowner develops the economically most attractive part of the plot and the dwellers build houses on the other part with full or limited 
land ownership. Land-sharing offers several advantages as governments are finding it increasingly difficult to find land for site-and-services and other public housing schemes in locations near income-generating activities, and eviction is increasingly becoming an unacceptable method to clear land for development projects.

\section{Conclusion}

From the research study, we can understand about the land policy instruments in Nepal. Moreover, the importance of the land policy framework, its rules and regulations and the various types of land registration systems which can lead to the organized urban development have also been clearly mentioned. The prominence of land tenure and property rights and the land use regulations for the growing urbanization is also of utmost compulsion. The need of the reformation emerges due to the limitations of the existing land policy and guidelines. Thus, the tools of urban land development like land acquisition, land development, land pooling and readjustment, GLD, land sharing and site and services can be used to improve the existing urban context of Nepal and create a poised urbanization in the fresh sites.

All landowners may not agree to sell their land but may agree to participate as a partner for their land development. Landowners may put their land for development as a partner but may not have finance to fund for the infrastructure. Likewise, landowners may not have expertise to make a land development project. Therefore, a partnership between landowner, financer (bank) and a planner would facilitate better land development through company act.

\section{Acknowledgements}

I would like to thank dean Dr. Prof. Bharat Pahari, Urban Planner P.B.Chhetri, Dr.Prof. Jiba Raj Pokharel, Dr. Prof. Bharat Sharma, program co-ordinater Miss Sudha Shrestha and very respected Urban Planner Kumar Lohani for inspiring me and guiding me to complete the research on the respective topic.

\section{References}

[1] Archer, R. W. (1984), Land Management for Adequate Land Supply and Planned Landuse in Asian Cities, HSD Research Paper No. 14, AIT, Bangkok.

[2] Archer, R. W. (1989), An Outline of Urban Land Policy for the Developing Countries of Asia, HSD Research Paper No. 20, AIT, Bangkok.

[3] Basnet, S. (2000), Land Readjustment as a Planning Tool for Urban Development, Thesis Dissertation, Institute of Engineering, Lalitpur, Nepal.

[4] CEDA (1990), Formation of Housing Policy, CEDA, Kathmandu

[5] CEDA (1992), Feasibility Study of Housing Industry in Kathmandu, CEDA, Kathmandu.

[6] Chhetri, P.B. (1986), Urban Land Policy Issues in Kathmandu Valley, Research Paper, pp 24, CEDR, University of California, Berkeley, USA.

[7] Chhetri, P.B. and Shrestha B.K. (1992), Documentation and Review of Site \& Services, Guided Land Development \& Land Pooling Projects in Nepal, DHUD/udle, Kathmandu.

[8] Chitrakar, B. (2000), Land Pooling and Urban Development- A Case Study of Kathmandu Valley, Thesis Dissertation, Institute of Engineering, Lalitpur, Nepal. 
[9] Doebele, W. A. (1985), Why Cadastral System are Important for Less Developed Countries in Land Registration and Cadastral System, ed. Gerhard Larsson, The Urban Edge 9, Longman \& Scientific, New York.

[10] Dowall, D. E. (1991), The Land Market Assessment: A New Tool for Urban Management in UMP, No. 4, World Bank/ UNDP/ UNCHS, Washington DC.

[11] Farvacque, C. and McAuslan, P. (1992), Reforming Urban Land Policies and Institutions in Developing Countries, Urban Management Program Discussion Paper No. 5, World Bank, Washington DC.

[12] GON/ KVTDC/ CDC (1999), Comparative Evaluation of the Usefulness of Site and Services and land Pooling Projects, Review Report, GON/ KVTDC, Kathmandu.

[13] Islam, N. (1998), Improving Urban Land Management in Bangladesh in Urban Land Management Improving Policies and Practices, eds. J. H. Ansari and N. V. Einsiedel, Oxford and IBH Publishing Company Pvt. Ltd., New Delhi.

[14] Kaiser, E. J. et. al., (1995), Urban Land Use Planning, University of Illinois Press, Urbana, Chicago.

[15] Larsson, G. (1991), Land Registration and Cadastral System: Tools of Land Information and Management, Longman Scientific and Technical, New York.

[16] PADCO (1986), Kathmandu Valley Urban Land Policy Study, GON/ USAID, Kathmandu.

[17] Rabenaw, B. V. (1989), Nepal Land Development Issues, submitted to udle, Kathmandu, Nepal.

[18] Upreti, S. (2001), Options for Private Sector Involvement Urban Land Development - A Case of Greater Kathmandu, Thesis Dissertation, Institute of Engineering, Lalitpur. 